\title{
Multiple intelligences and minds as attributes to reconfigure PR? A critical analysis
}

\author{
Jim Macnamara \\ University of Technology Sydney
}

The fields of business and management with which public relations interacts and in which it is often located are rife with concepts, models and theories on leadership, performance, and effectiveness. Recently these have turned attention to alleged multiple forms of intelligence, such as Howard Gardner's claims for eight types of intelligence, which have been expanded by others to as many as 150. Gardner also proposed that humans have five minds and claimed that application of these diverse intelligences and minds can enhance human interactions and relationships. This article critically reviews the potential of these concepts and theories to reconfigure PR, identifying some useful insights, but also raising fundamental theoretical questions.

Keywords: Public relations, intelligences, minds, mindfulness, standpoint

\section{General understandings of intelligence}

Typical dictionary definitions of intelligence describe it as:

1: the ability to learn or understand or to deal with new or trying situations; the skilled use of reason. 2: the ability to apply knowledge to manipulate one's environment or to think abstractly as measured by objective criteria or tests (Merriam-Webster, 2014).

Scholarly definitions of what they call 'general intelligence' include Schmidt and Hunter's (2000) description of it as the ability to learn and solve problems. Gardner and Hatch similarly define human intelligence as "the capacity to solve problems or to fashion products that are valued in one or more cultural setting” (1989, p. 5). Resnik (2002) also refers to learning, and an ability to apply "reason" appears in many discussions of intelligence (e.g., Cismaru \& Ciochina, 2014, p. 4). In summary, these and other common definitions associate intelligence with learning and applying knowledge; with dealing with new situations; with understanding; and particularly with applying reason and thinking abstractly with a view to solving problems.

While the key concepts identified in these definitions are useful in disrupting populist notions of intelligence - that is, intelligence is not simply about brain cells or something innate that we are born with at a fixed level, but rather it is created through learning, gaining knowledge, and practicing to gain abilities - there are elements of these common definitions that are troubling and warrant challenge. The first is the focus on reason and objective criteria, which implies a logico-deductive scientific approach and positivist or post-positivist thinking informed by quantitative research methods. Postmodern researchers argue that humans are interpretivist and constructivist and that their perceptions and behaviors are influenced by affective as well as rational cognitive processes (Denzin \& Lincoln, 2008).

Beyond mechanistic and systems thinking, Shockley-Zalabak (1994) argues that "interpretative-symbolic-culture" orientated approaches need to be applied to communication (pp. 3-5). In short, the human mind is essentially humanistic as well as capable of scientific processes. Also, the focus on solving problems suggests a functionalist view sociologically and in organizational contexts and an implicit objective of effectiveness which, in the face of 
inequities in power and neoliberal capitalist thinking, can result in intelligence being used to manipulate one's environment and fashion products in socially inequitable and undesirable ways. But such concerns have been overtaken by a number of new theories and arguments about intelligence that raise new notions, possibilities, and questions.

\section{The alleged discovery of multiple intelligences}

\subsection{Emotional intelligence}

Perhaps the traditional rational, objective, scientifically orientated understanding of human intelligence is the reason that some psychologists, including a few 'pop psychologists', have proposed emotional intelligence as a way of thinking and applying our intellect. Abbreviated to EI, the concept is more often referred to as EQ following the tradition of measuring intelligence using tests that calculate an Intelligence Quotient (IQ). Mayer and Salovey, who coined the term 'emotional intelligence' in the 1990s, define EQ as "the ability to perceive emotion, integrate emotion to facilitate thought, understand emotions, and to regulate emotions to promote personal growth" (1997, p. 10). Here we have recognition that being smart is not just about logic, reason and science.

Two types of EQ are proposed: (a) trait based emotional intelligence and (b) ability orientated emotional intelligence. Soviet-born British psychologist Konstantin Petrides who advocated a distinction between the ability based model and a trait based model has developed and advocated the latter concept over many years. He argues that Trait EQ is "a constellation of emotional self-perceptions located at the lower levels of personality" (Petrides \& Furnham, 2000). Trait EQ refers to an individual's self-perceptions of their emotional abilities and is measured by self-reporting, whereas Ability EQ is based on demonstrated abilities.

Trait EQ seems to take us back to the 'nature versus nurture' argument and specifically to the much-criticized view that intelligence is entirely in our genes, which led to the Modernist notion of the born genius. On the other hand, Ability EQ proposes five learned abilities: (a) "self-awareness" which Eysenck says is the "keystone of emotional intelligence"; (b) managing one's emotions; (c) "marshaling emotions in the service of a goal”, which could be termed motivating oneself; (d) recognizing emotions in others; and (e) handling relationships by managing emotions in others sensitively and effectively (Eysenck, 2000, p. 109). While these are all eminently supportable principles, even commonsensical, they beg the question 'why not simply call them abilities rather than refer to them as new types of intelligence?' A number of scholars have asked this question, as we will see.

Goleman (1998) proposed a 'mixed model' of EQ that focuses on a wide array of competencies and skills allegedly associated with leadership and performance including selfawareness, self-regulation, social skills to motivate people in desired ways, empathy, and motivation, and he played a key role in making emotional intelligence a popular concept in management.

However, in concert with a number of scholars who criticize the concept of emotional intelligence, Eysenck (2000) says that Goleman's description of EQ contains unsubstantiated assumptions about intelligence and that it lacks any scientific basis. He states that Goleman:

exemplifies more clearly than most the fundamental absurdity of the tendency to class almost any type of behavior as an 'intelligence' ... If these five 'abilities' define 'emotional intelligence', we would expect some evidence that they are highly correlated; Goleman admits that they might be quite uncorrelated, and in any case if we cannot measure them, how do we know they are 
related? So the whole theory is built on quicksand: there is no sound scientific basis/ (Eysenck, 2000, p. 109)

In his book titled Psychobabble: Exploding the Myths of the Self-help Generation, Briers (2012) points out that Salovey and Mayer (1989) were quite circumspect in their original definition of emotional intelligence. Briers says that in their view, emotional intelligence resembled other forms of intelligence, or even was the same thing, and that it "was distinguished chiefly by the specific type of data upon which it operated" (n. p.). In short, it was intelligence that considered emotions as well as logic and reason.

In a similar critique, Locke (2005) says that what is described is not another form or type of intelligence, but simply intelligence applied to a particular life domain. He suggests the concept should be re-labeled and referred to as a skill. Or we can simply refer to these humanistic elements as abilities that complement other abilities based on scientific processes. Nevertheless, the belief in multiple forms of intelligence has persisted through the $20^{\text {th }}$ century and into the $21^{\text {st }}$ century.

\subsection{Collective intelligence}

Sociologist Pierre Lévy (1997) argued for the existence and importance of collective intelligence, referring to the capacity of groups of people to cooperate and collaboratively solve problems and generate new knowledge beyond what any individual can accomplish colloquially referred to as the 'wisdom of the crowd'. This challenges elitist views of intelligence, knowledge and power and the singular individualistic concepts of IQ and EQ.

In recent times, the notion of collective intelligence has gained momentum with the proliferation of Web 2.0-based social media and social networks, which have enabled largescale collaborations such as the Mars Clickworkers project in which more than 80,000 amateur astronomers helped NASA identify around two million craters on Mars and classify the relative age of another 300,000 - a project that would have taken scientists years, if not decades, to complete. Significantly, American Scientist reported that this collaborative public effort was almost as accurate as work done by expert planetary geologists (Szpir, 2002). In 2013, Google released maps of North Korea based on several years of collaborative effort by “a community of citizen cartographers" (Mysore, 2013, para. 2).

\subsection{Digital intelligence}

Borrowing from Lévy's concept of collective intelligence as well as widespread evidence of the growing use and importance of digital technologies including the internet as a global communications infrastructure reported by many scholars including Bucy (2004), Deibert (1997) and Lievrouw and Livingstone (2002), Adams (2004) proposed digital intelligence as a new form of intelligence involving a response to the cultural change brought about by digital technologies. Adams acknowledged that digital intelligence as made up of “components of other intelligences” (2004, p. 99), although scholars such as van Dijk (2006) and van Deursen and van Dijk (2009) have echoed Locke's (2005) warning that these components are better termed skills, with the latter identifying the need for operational, information, formal and strategic skills.

\subsection{Creative intelligence}

Recently, scholarly as well as business and management attention have been devoted to creative intelligence, referred to as CQ (Nussbaum, 2013). It is quite difficult to find a clear agreed definition of creative intelligence and, as Briers (2012) and Locke (2005) argue in relation to emotional intelligence, when the rhetoric is stripped away it seems to simply be human intelligence applied in a particular way - in this case to developing abilities to be 
creative. Nevertheless, creative intelligence is a popular concept with politicians and industry leaders today as nations seek new opportunities for economic growth and competitive advantage. A number of universities have introduced courses and even whole degrees focused on creative intelligence such as the Bachelor of Creative Intelligence and Innovation (BCII) degree at the University of Technology Sydney (2014).

\subsection{Gardner's eight intelligences}

One of the most extravagant views of human intelligence was advanced by J. P. Guildford who claimed in his book A Structure of Intellect Theory that there are 120 separate types of human intelligence, and later expanded this to 150 (Eysenck, 2000, p. 108). However, the person who has been most successful in promoting the notion of multiple intelligences is Harvard University developmental psychologist Howard Gardner. In his widely cited book Frames of Mind: The Theory of Multiple Intelligences, Gardner proposed seven types of intelligence as follows:

- Mathematical/logical - the capacity to analyse problems logically and carry out mathematical operations;

- Linguistic/verbal - sensitivity to spoken and written language and the capacity to use language to accomplish goals;

- Spatial - the potential to recognize and use the patterns of wide/open space as well as confined spaces;

- Body-kinesthetic - the potential to use one's body or parts of the body to solve problems, including physical coordination. Gardner saw mental and physical activity as related;

- Musical/rhythmic - skill in the performance, composition and appreciation of musical patterns including the capacity to recognize and compose pitches, tones and rhythms;

- Interpersonal - the capacity to understand the intentions, motivations and desires of people and ability to work effectively with others;

- Intrapersonal - the capacity to understand oneself and appreciate one's own feelings, fears, motivations and limitations as well as strengths (Gardner, 1993).

Gardner later introduced naturalistic intelligence - the ability of humans to recognize, categorize and draw upon certain features of their environment - to his original list to make up his eight types of human intelligence (Gardner, 1999).

Gardner also considered and discussed spiritual, existential and moral intelligence (closely related concepts concerned with “ultimate issues” such as recognizing 'truth' and recognizing the sanctity of human life). He said existential intelligence "scores reasonably well on the criteria", however, he added: "I find the phenomenon perplexing enough and the distance from the other intelligences vast enough to dictate prudence - at least for now" (Gardner, 1999, p. 66). He argued that there was not enough empirical evidence to establish the spiritual or moral dimensions of thought as an intelligence - although critics make that claim about most or all of the other types of intelligence he proposed.

The descriptions of each of Gardner's eight intelligences explicitly refer to skills, capacities and potential. As such, it can be legitimately argued that they are applications of human intelligence as described in other definitions - not a particular form of intelligence. The differentiation that Gardner and others seek seems to be more to do with escaping from the positivist paradigm of logico-deductive thinking based on empirical data as a framework for applying intelligence and embracing the affective - that is, emotion, as well as cognition. Whereas emotional reactions and human subjectivities are often ignored or even derided in scientific modernist contexts, the search for multiple intelligence signals a recognition that 
success in living, managing and interacting with other people requires behavior that draws on and taps human emotions as well as logical rational cognition.

\subsection{Even more types of intelligence}

There also have been claims for cultural, social, critical, analytical and practical intelligences (Sternberg, 1985). These can be similarly seen as domains or settings for the application of human intelligence, rather than some distinct new form of human intellectual processing. In addition, there are other long-standing types of intelligence referred to in military, intelligence and security services, and business such as military intelligence and competitive intelligence which have been extensively discussed in specialist literature such as business and management texts (e.g., Knip, Dishman, \& Fleisher, 2003). However, the focus here is on more recent claims of multiple intelligences applied in human interaction, such as those summarized in Table 1.

Table 1. Some of the types of human intelligence claimed in the literature.

\begin{tabular}{ll}
\hline General intelligence (Schmidt \& Hunter, 2000) & Interpersonal intelligence (Gardner, 1993) \\
\hline Emotional intelligence (Mayer \& Salovey, 1997) & Intrapersonal intelligence (Gardner, 1993) \\
\hline Collective intelligence (Lévy 1997) & Naturalistic intelligence (Gardner, 1993) \\
\hline Creative intelligence (Nussbaum, 2013) & Cultural intelligence (Sternberg, 1985) \\
\hline Mathematical/logical intelligence (Gardner, 1993) & Social intelligence (Sternberg, 1985) \\
\hline Linguistic/verbal (Gardner, 1993) & Analytical intelligence (Sternberg, 1985) \\
\hline Spatial intelligence (Gardner, 1993) & Practical intelligence (Sternberg, 1985) \\
\hline Body-kinesthetic intelligence (Gardner, 1993) & Competitive intelligence (Knip, et al., 2003) \\
\hline Musical/rhythmic intelligence (Gardner, 1993) & Digital intelligence (Adams, 2004) \\
\hline
\end{tabular}

While some of these understandings of intelligence and the human mind have significantly influenced education and learning, as well as management and organizational communication, and gained some scholarly support, many are criticized for unsubstantiated assumptions and lack of empirical evidence, as already noted, as well as definitional looseness (e.g., Eysenck, 2000; Locke, 2005). Eysenck refers to "the fundamental absurdity of the tendency to class almost any type of behavior as an 'intelligence'” (2000, p. 109) and Locke says that what is described is not another form or type of intelligence, but simply intelligence - the human ability to comprehend abstractions - applied to particular situations. He and other critics suggest that many of the concepts are 'pop psychology' and should be relabeled and referred to as a skills, abilities, knowledge, or ways of thinking. Certainly it has to be recognized that several of the so-called intelligences discussed are not supported by rigorous research.

However, the one useful purpose that these multiple claims for various types of intelligence serve is to draw attention away from traditional focus on rationality, reason and the prioritizing of mathematical dimensions of intelligence, as well as quantitative 'scientific' approaches to understanding and measuring intelligence and draw attention to emotional, interpersonal, intrapersonal, social, cultural and humanistic dimensions of human thought and behaviour.

\subsection{Holistic intelligence}

Rather than debate various types of intelligence, it might be more productive to refer to 'holistic intelligence' to emphasize that human intelligence should be applied drawing on the 
full range of human faculties and, in particular, incorporating emotion as well as cognition; the humanistic as well as the scientific.

This is relevant to public relations, which, particularly in the dominant North American model, is positioned as the 'science of communication' (e.g., see Institute for Public Relations, 2014). While noting a lack of evidence to support the many of the theories of multiple intelligences, public relations should take note of the broadening of thinking about intelligence - specifically, the shift from narrow approaches based on logic, rationality and reason (e.g., facts and figures and information) to more holistic approaches that recognize that humans experience the world, construct reality, and interact based on both emotion and cognition and that reality is largely constructed by humans, not simply discovered or thought out through rationality and reason..

Also, whether one accepts them as intelligences or as abilities and capacities, public relations practice needs to be conscious of and incorporate consideration of not only language expressed in words and images - our 'bread and butter' if you like - but tone, pitch, and rhythm; physical, social and cultural space; sensitivity to others' feelings, needs, fears and motivations; self-awareness (reflexivity); and problem solving using logic, reason and even mathematics such as metrics for measurement and evaluation and reporting to management. While this researcher remains highly skeptical of so-called multiple intelligences, the skills and capacities that they refer to help us identify what is required to be a 'holistic communicator' and a 'holistic' manager.

\section{Minds and mindfulness}

A related concept that also has captured attention in management recently - it is probably not accurate to call it a theory - is Gardner's 'five minds', which he says afford important ways of thinking about the future (Gardner, 2007). Gardner's more recent work has built on his theory of multiple intelligences to propose that humans possess 'five minds', the first three of which - the disciplined, synthesizing, and creative minds - are related to intellect, while the other two - the respectful and ethical minds - relate to character (Gardner, 2007).

The disciplined mind refers to acquiring knowledge within a particular discipline or field, such as mathematics, science, history, and so on, which remains foundational to learning according to Gardner. However, he argues that in today's information-saturated world with more and more information available digitally, a synthesizing mind is increasingly essential to sift, sort, combine, compare, and condense information to make sense of it. Thirdly, he proposes that once students have acquired disciplinary knowledge and synthesized it, rather than simply applying what they know, the industries of the future will require them to 'think outside the box', which requires a creative mind. Directing his comments largely towards the education sector, he says educators need to address all three minds in students' intellectual development, rather than simply pumping students full of disciplinary knowledge. In addition, he says that a just and fair society requires development of a respectful mind and an ethical mind.

Again, much of what Gardner says about multiple minds is regarded as pop psychology and one should critically ask what's new about the idea that humans should be knowledgeable about their field of activity, able to synthesize information, be creative, be respectful of others, and act ethically. Most of these attributes have been taught for centuries by parents, school teachers, and universities. 
However, if one goes back to common definitions of 'mind', we can see that what Gardner is reacting to is a narrow understanding formed by the Enlightenment project and the scientific tradition that has dominated research and knowledge construction during the period of Modernism and Late Modernism. Mind is commonly defined as:

1: in a human (or other conscious being) the element, part, substance, or process that reasons, thinks, feels, wills, perceives, judges, etc. 2: the totality of conscious and unconscious mental processes and activities. 3: intellect or understanding, as distinguished from the faculties of feeling and willing; intelligence (Dictionary.com, 2014).

The Oxford Dictionaries online defines mind as:

The element of a person that enables them to be aware of the world and their experiences, to think, and to feel; the faculty of consciousness and thought (2014).

While the term 'feel' is used in both definitions, the first specifically distinguishes the mind from feeling and associates it with reason, intellect, and intelligence. These descriptions show that the human mind is predominantly conceived as an organ of cognition. Also, in popular usage mind is mostly synonymous with thought - not feelings or emotions. Thus, while Gardner may be overstretching to claim that humans have five minds, his emphasis on balancing disciplinary knowledge, creativity, respect based on feelings for other humans, and ethics, as well as an ability to synthesize large amounts of information, is arguably very relevant for professionals in all fields and particularly for professional in public communication and public relations.

This broader concept of the human mind, involving both affective and cognitive elements and processes, also links to the concept of mindfulness. While this too is mired in much pop psychology and self-help literature, mindfulness is nevertheless a clinically recognized condition used for promoting psychological wellbeing and treating depression (Brown \& Ryan, 2003). In a book on the concept, Langer says "when we are mindful, we are open to surprise, oriented in the present moment, sensitive to context, and above all, liberated from the tyranny of old mindsets" (1989, p. xiv). Thus, mindfulness can be seen to correlate with self-awareness and sensitivity to others, key attributes of emotional intelligence, as well as spatial, interpersonal, and naturalistic intelligence, and the respectful, ethical and creative minds proposed by Gardner.

It can be argued that an overarching attribute required of public relations is mindfulness and that a key function of PR is creating 'organizational mindfulness', which requires selfawareness of the power, responsibilities, strengths, weaknesses and interdependencies of the organization; sensitivity to its environment (physical, social, cultural and political), ethical concern; and openness to creative and innovative ways to solve problems and create harmony and wellbeing.

However, as much as this may be useful, it is argued that critical analysis of such concepts and theories as discussed here needs to go one step further because all of these attributes, skills, abilities, and what one is mindful of, do not exist and are not applied in a vacuum or in a neutral value-free, socially sterile environment. While public relations theory building has recognized many elements of context (e.g., power) and contextualizing theories such as framing, priming, and orientation, it has curiously largely ignored one fundamentally important theory related to where one stands socially, culturally, politically, economically, and ideologically in making assessments, undertaking learning, and developing and applying skills. 


\section{Standpoint theory}

Standpoint theory provides a postmodern method for analyzing inter-subjective discourses that recognizes the pivotal role of individuals' and organizations' location in social, cultural and political space (Griffin, 2009; Rolin, 2009). It shows that how we think and act is framed, and limited, by our standpoint, not only our intelligence and mind processes. Indeed, what our mind and intelligence(s) can see and process is determined by our social, cultural, political and economic vantage point. Standpoint is more than a perspective in a general sense; it is the relative position of power, access, status, and privilege from which an individual or a group with shared characteristics encounters the world, which standpoint theorists argue determines what they see and what is obscured and, therefore, what they know.

Standpoint theory began when Hegel studied the different standpoints between slaves and masters in 1807 (Wood, 2008). He observed that the master-slave relationship affected how each received knowledge and their relative power, and ultimately shaped everything they thought or 'knew' about themselves, others, and society (Griffin, 2009, pp. 441-443). Marx drew on Hegel to write about how the position of workers shaped their knowledge and perceptions - i.e., a proletarian standpoint. Standpoint theory came to prominence in feminist critiques, such as the work of Harding (1986, 1987, 1991); Harding \& Hintikka, (1983), Smith $(1974,1979,1987)$, and Hartsock (1983a, 1983b, 1987) in which it was used to examine the relative positions of women and men in society.

Feminist standpoint theory has been criticized for essentialism and universalizing in allegedly claiming that certain groups, such as women, have homogenous characteristics that enable them to share a common standpoint, and particularly for the concept of 'strong objectivity' introduced by Harding. This concept, drawn from Hegel and Marx, proposes that those with unprivileged social positions are likely to have perspectives that are "less partial and less distorted" than the perspectives of the privileged (Harding, 1991, p. 121). Harding further explains: "When people speak from the opposite sites of power relations, the perspective from the lives of the less powerful can provide a more objective view than the perspective from the lives of the more powerful” (1991, pp. 269-270.) Some scholars such as Rolin (2009) counter that criticisms, particularly those related to essentialism, involve misinterpretations of feminist standpoint theory, which continues to inform gender studies and research into marginalized groups.

This analysis skirts around this debate leaving the contentious concept of 'strong objectivity' as well as other specific aspects of feminist standpoint theory to the side, noting that some scholars such as Wood $(1993,1997)$ have shown the benefits of applying standpoint theory to communication more broadly. Wood argues that all perspectives are partial and that some standpoints are "more partial than others since different locations within social hierarchies affect what is likely to be seen” (1993, p. 13).

It is argued here, however, that the central tenets of standpoint theory, particularly as it is applied to communication, can usefully inform the intelligence/s (ways of thinking) and mindfulness applied in public relations because it can be argued that all learning, thinking, reasoning, and one's ability to perceive, feel, empathize, and understand others are determined by one's standpoint.

But, interestingly, standpoint theory has been seldom applied in PR, other than specific studies of gender issues using feminist standpoint theory (e.g., Daymon \& Demetrious, 2014; Pompper, 2007; Rakow \& Nastasia, 2009). As important as such studies and uses of 
standpoint theory are, two broader fundamental concepts in contemporary public relations theory are brought into critical focus by standpoint theory. These are (a) the notion of 'boundary spanning' and (b) the orthodoxy that PR needs to be positioned in the 'dominant coalition’ of employer organizations.

Central to claims that public relations can build and maintain relationships between organizations and their publics (Grunig \& Hunt, 1984), stakeholders (Freeman, 1984), and stakeseekers (Heath, 2002; Heath \& Coombs, 2006; Spicer, 2007) is the grand claim that PR practitioners perform a function of boundary spanning, in which Grunig and Hunt say they "have one foot in the organization and one outside" (1984, p. 9). Allegedly, PR practitioners are able to understand and represent the perspectives of publics, stakeholders and stakeseekers to the organization as well as understand and represent the perspectives of the organization to these individuals and groups. The alleged capability of PR to perform a boundary spanning role is deeply entrenched in PR theory (e.g., Grunig, 1992; Grunig \& Hunt, 1984; L. Grunig, J. Grunig, \& Dozier, 2002). But standpoint theory introduces serious questions about, if not outright rejection of, the notion of PR boundary spanning. In particular, standpoint theory problematizes the boundary spanning role of PR when PR is predominantly practiced by white, Anglo, Westernized, highly educated, mostly middle class practitioners, which is the case in most developed countries (PRCA, 2013; Toth, 2009).

The capacity of PR practitioners to know, understand, empathize with, and build mutuallysatisfying relationships with publics, stakeholders, and stateseekers is made even more problematic by widely-propagated doctrine that PR should ideally be located in the 'dominant coalition' of employer organizations (Berger, 2005; Berger \& Reber, 2006; Grunig et al., 2002). The dominant coalition of an organization is conceptualized in management studies as the network of individuals within and around an organization that most influence its goals, policies, and operations (Bowler, 2006). The goals, policies, and operations of an organization derive to a large extent from the chief executive officer, the board of directors, and the senior management team. Nevertheless, in organizational and management theory the dominant coalition is seen to exercise its influence through informal, rather than formal, channels. Bowler writes that "top management members are typically, but not exclusively or necessarily, members of the dominant coalition". He says that "coalition members need not be within the organization", adding that "suppliers, customers, or other stakeholders with significant control over the organization's distribution channels or decisions could exercise influence within the dominant coalition” (2006, p. 261).

However, while noting organizational and management definitions of the dominant coalition, PR theory largely focuses on the senior management team inside the organization. For instance, in the third and ultimate PR Excellence theory text, Grunig et al. state: "The dominant coalition is the group of individuals within the organization who have the power to determine its mission and goals. They are the top managers who 'run' the organization (2002, p. 141).

While 'the dominant paradigm' of public relations embodied in Excellence theory advocates formative research to identity publics' and stakeholders' views, interests and needs, two-way asymmetric and symmetrical communication, dialogue, co-orientation and accommodation, (Broom, 1977; L. Grunig, J. Grunig, \& Dozier, 2002; Kent \& Taylor, 2002), critics argue that much if not most PR practice is organization-centric - that is, focused on the objectives, needs and interests of the organization (Leitch \& Neilson, 2001; L'Etang, 2008). Jim Grunig rejects claims that PR is organization-centric when practiced according to Excellence theory, pointing to specific exaltations that "public relations should serve the interests both of organizations and society” (Grunig et al., 2002, p. 11). However, literature on measurement 
and evaluation supports the argument that, in practice, PR is primarily undertaken to achieve the objectives of the employer organization - and often specifically to serve the interests of business (e.g., Institute for Public Relations, 2010; Macnamara, 2014). This standpoint is also explicitly evident in contemporary writing by PR scholars such as a recent article by Duhé who advocates the teaching of business as a "second language" of public relations, claiming that "business literacy makes one a better communication strategist" and calling for the "melding of business objectives with communication objectives" (2013, paras 5-6). While 'melding' might suggest balance, PR and 'strategic communication' literature are heavily orientated towards the interests of the large corporations and government departments and agencies that are the main employers of PR.

Standpoint theory raises major questions about the extent to which PR practitioners employed by corporations and government working in and for the dominant coalition can recognize, understand, and reflect the interests, concerns, and needs of publics, stakeholders and stakeseekers, particularly those in minority groups and those marginalized from mainstream society and centers of power. Standpoint theory does not claim that seeing and understanding another's position is impossible, but it points out that high levels of reflexivity as well as reflectivity are required, along with critical thinking and naturalistic interpretivist research such as ethnography. Thus, we can conclude that reconfiguring PR to better achieve dialogue, co-orientation, mutuality, and relationships, demands a significant mind-shift.

Derina Holtzhausen's proposal for PR practitioners to work as organizational activists (Holtzhausen, 2007; Holtzhausen \& Voto, 2002) practicing "professional activism and dissent” (Berger \& Reber, 2006) is impractical in most corporate and organizational PR roles. However, there are models to inform alternative approaches in PR. For example, legal counsel and auditors serve organizations and society through a neutral or at least semiindependent position, empowered by their knowledge and specialist expertise - albeit they also have regulatory authority in most countries. If these models are too lofty for PR practitioners to aspire to and achieve, the broader role of public diplomacy provides insights with its focus on maintaining dialogue (even in the face of complete disagreement), use of protocols such as equal size delegations and turn-taking, mechanisms such as arbitration, and ombuds (L’Etang, 2008; Macnamara, 2012; Signitzer \& Wamser, 2006).

\section{Conclusions}

This critical analysis draws three key conclusions.

\subsection{Beware 'pop psychology' - but note the ground shift}

First, this critical analysis sounds caution in relation to the concept of multiple intelligences and multiple minds, warning of 'pop psychology' arguments presented in many cases and a lack of clinical or scholarly evidence. Nevertheless, it concludes that focus on allegedly new types of intelligence, such as emotional intelligence and interpersonal intelligence and calls for creative, respectful and ethical minds, as well as disciplined and synthesizing minds, signals a shift away from narrow scientific approaches that associate intelligence with cognition based on logic and reason to include emotion (i.e., feelings) and recognize humanistic as well as scientific factors. This is to be welcomed.

\subsection{Apply holistic intelligence and mindfulness - not just strategies and numbers}

This analysis suggests that all fields of management including public relations should apply 'holistic intelligence' drawing on the full range of human faculties and abilities - affective as well as cognitive - including intrapersonal (self-awareness), naturalistic (environmental awareness), interpersonal, spatial, body-kinesthetic, and musical/rhythmic, as well as 
linguistic and mathematical. Furthermore, it has proposed that public relations practice requires a broad interpretation of mindfulness incorporating disciplinary knowledge, synthesizing abilities, creativity, respectfulness, and ethics and that PR could and should play a leading role in creating 'organizational mindfulness' that reflects these qualities.

\subsection{PR needs to change its standpoint to reconfigure its future}

While noting normative theories of dialogue, co-orientation, symmetry, and relationships that comprise 'the dominant paradigm' of PR today, and acknowledging their ethical intent, and the specific sociocultural focus of emerging critical theories of PR (e.g., L'Etang, 2008, Edwards \& Hodges, 2011), future PR scholarship and practice require greater attention to standpoint as informed by standpoint theory, which problematizes the concepts of positioning PR within the dominant coalition of organizations and boundary spanning. Standpoint theory also challenges the dominant scientific and largely functionalist approach to PR and informs an interpretivist/constructionist approach utilizing in-depth qualitative research methods such as ethnography and involving reflexivity, reflectivity, and critical analysis. With global business leaders proposing that organizations need to become a "social organization" applying the collective intelligence of their employees and customers (e.g., Bradley \& McDonald, 2011) and that businesses need to operate as a "social business" (IBM, 2011), these theories and concepts defy dismissal as Leftist philosophy and point to the future of organization-public relations and communication in the $21^{\text {st }}$ century.

\section{References}

Adams, N. (2004). Digital intelligence fostered by technology. Journal of Technology Studies, 30(2), 93-97.

Berger, B. (2005). Power over, power with, and power to relations: Critical reflections on public relations, the dominant coalition, and activism. Journal of Public Relations Research, 17(1), 5-27.

Berger, P., \& Reber, B. (2006). Gaining influence in public relations: The role of resistance in practice. Mahwah, NJ: Lawrence Erlbaum.

Bowler, M. (2006). Organizational goals versus the dominant coalition: A critical view of the value of organizational citizenship behavior. Journal of Behavior and Applied Management, 7(3), 258277.

Bradley, A., \& McDonald, M. (2011). The social organization: How to use social media to tap the collective genius of your customers and employees. Boston, MA: Harvard Business Review Press.

Briers, S. (2012). Psychobabble: Exploding the myths of the self-help generation. Harlow, UK: Pearson Education.

Broom, G. (1977). Co-orientational measurement in public issues. Public Relations Review, 3, 110 119.

Brown, K., \& Ryan, R. (2003). The benefits of being present: Mindfulness and its role in psychological well-being. Journal of Personality and Social Psychology, 84(4), 822 -848.

Bucy, E. (2004). Interactivity in society: Locating an elusive concept. Information Society, 20(5), 373-383.

Cismaru, D., \& Chiochina, R. (2014, June). The rise of digital intelligence: Challenges for public relations education and practice. Paper presented to the $4^{\text {th }}$ Barcelona International Public Relations Meeting, Barcelona, Spain.

Daymon, C., \& Demetrious, K. (Eds.). (2014). Gender and public relations: Critical perspectives on voice, image and identity. New York, NY: Routledge.

Deibert, R. (1997). Parchment, printing, and hypermedia: Communication in world order transformation. New York, NY: Columbia University Press.

Denzin, N., \& Lincoln, Y. (Eds.). (2008). Strategies of qualitative inquiry. Thousand Oaks, CA: Sage.

Dictionary.com. (2014). Mind. Retrieved from http://dictionary.reference.com/browse/mind

Duhé, S. (2013). Teaching business as a second language. Gainesville, FL: Institute for Public Relations. Retrieved from http://www.instituteforpr.org/2013/12/teaching-business-secondlanguage 
Edwards, L., \& Hodges, C. (Eds.). (2011). Public relations, society and culture: Theoretical and empirical explorations. Abingdon, UK: Routledge.

Eysenck, H. (2000). Intelligence: A new look. Brunswick, NJ: Transaction Publishers.

Freeman, R. (1984). Strategic management: A stakeholder approach. London: Pitman Publishing.

Gardner, H. (1993). Frames of mind: The theory of multiple intelligences. London, UK: Fontana. (original work published 1983, New York, NY: Bantam Books)

Gardner, H. (1999). Intelligence reframed: Multiple intelligences for the $21^{\text {st }}$ century. New York, NY Basic Books.

Gardner, H. (2007). Five minds for the future. Cambridge, MA: Harvard Business School Press.

Gardner, H., \& Hatch, T. (1989). Multiple intelligences go to school: Educational implications of the theory of multiple intelligences. Educational Researcher, 18(8), 4-9.

Goleman, D. (1998). Working with emotional intelligence. New York, NY: Bantam Books.

Griffin, E. (2009). A first look at communication theory ( $7^{\text {th }}$ ed.). New York, NY: McGraw-Hill.

Grunig, J., \& Hunt, T. (1984). Managing public relations. Orlando, FL: Holt, Rinehart \& Winston.

Grunig, L., Grunig J., \& Dozier D. (2002). Excellent organizations and effective organizations: A study of communication management in three countries. Mahwah, NJ: Lawrence Erlbaum.

Harding, S., \& Hintikka, M. (Eds.). (1983). Discovering Reality: Feminist perspectives on epistemology, metaphysics, methodology and philosophy of science. Boston, MA: Reidel.

Harding, S. (1986). The science question in feminism. Ithaca, NY: Cornell University Press

Harding, S. (Ed.). (1987). Feminism and methodology. Bloomington, IL: Indiana University Press.

Harding, S. (1991). Whose science? Whose knowledge? Thinking from women's lives. Ithaca, NY: Cornell University Press.

Hartsock, N. (1983a). The feminist standpoint: Developing the ground for a specifically feminist historical materialism. In S. Harding \& M. Hintikka (Eds.), Discovering reality: Feminist perspectives on epistemology, metaphysics, methodology, and the philosophy of science (pp. 283310). Dordrecht, The Netherlands: Reidel.

Harstock, N. (1983b). Money, sex and power. New York, NY: Longman.

Hartsock, N. (1987). The feminist standpoint: Developing the ground for a specifically feminist historical materialism. In S. Harding (Ed.), Feminism and methodology (pp. 157-180).

Bloomington, IL: Indiana University Press

Heath, R. (2002). Issues management: Its past, present and future. Journal of Public Affairs, 2(2), 209-214.

Heath, R., \& Coombs, T. (2006). Today’s public relations: An introduction. Thousand Oaks, CA: Sage.

Holtzhausen, D. (2007). Activism. In E. Toth (Ed.), The future of excellence in public relations and communication management (pp. 357-379). Mahwah, NJ: Lawrence Erlbaum.

Holtzhausen, D., \& Voto, R. (2002). Resistance from the margins: The postmodern public relations practitioner as organizational activist. Journal of Public Relations Research, 14(1), 57-84.

IBM. (2011). The social business: Advent of a new age. White Paper. Retrieved from http://www.ibm.com/smarterplanet/global/files/us_en_us_socialbusiness_epw14008usen.pdf

Institute for Public Relations. (2010). Barcelona declaration of measurement principles. Gainesville, FL. Retrieved from http://www.instituteforpr.org/topics/barcelona-declaration-of-measurementprinciples

Institute for Public Relations. (2014). About us. Retrieved from http://www.instituteforpr.org/about

Kent, M., \& Taylor, M. (2002). Toward a dialogic theory of public relations. Public Relations Review, 28, 21-37.

Knip, V., Dishman, P., \& Fleisher, C. (2003). Bibliography and assessment of key competitive intelligence scholarship: Part 3 (The earliest writings -1989). Journal of Competitive Intelligence and Management, 1(3), 10-79.

Langer, E. (1989). Mindfulness. Reading, MA: Addison-Wesley/ Longman.

L'Etang, J. (2008). Public relations: Concepts, practice and critique. London, UK and Thousand Oaks, CA: Sage.

Leitch, S., \& Neilson, D. (2001). Bringing publics into public relations: New theoretical frameworks for practice. In R. Heath (Ed.), Handbook of public relations (pp. 127-138). London, UK: Sage.

Lévy, P. (1997). Collective intelligence: Mankind's emerging world of cyberspace. Cambridge, MA: Perseus Books.

Lievrouw, L., \& Livingstone, S. (Eds.). (2002). The handbook of new media. London, UK: Sage. 
Locke, E. (2005). Why emotional intelligence is an invalid concept. Journal of Organizational Behavior, 26(4), 425-431.

Macnamara, J. (2012). Corporate and organizational diplomacy: An alternative paradigm to PR. Journal of Communication Management, 16(3), 312-325.

Macnamara, J. (2014). Emerging international standards for measurement and evaluation of public relations: A critical analysis. Public Relations Inquiry, 3(1), 7-28.

Mayer, J., Salovey, P. (1997). What Is Emotional Intelligence? In P. Salovey \& D. Sluyter (Eds.), Emotional development and emotional intelligence: Implications for educators (pp. 3-31). New York, NY: Basic Books.

Merriam-Webster. (2014). Intelligence. Retrieved from http://www.merriamwebster.com/dictionary/intelligence

Mysore, J. (2013, January 28). Publishing more detailed maps on North Korea. Google Maps, blog post. Retrieved from http://google-latlong.blogspot.com.au/2013/01/publishing-more-detailedmaps-of-north.html

Nussbaum, B. (2013). Creative intelligence: Harnessing the power to create, connect and inspire. New York, NY: Harper Collins.

Oxford Dictionaries. (2014). Mind. Retrieved from http://www.oxforddictionaries.com/definition/english/mind

Petrides, K., \& Furnham, A. (2000). On the dimensional structure of emotional intelligence. Personality and Individual Differences, 29, 313-320.

Pompper, D. (2007). The gender-ethnicity construct in public relations organizations: Using feminist standpoint theory to discover Latinas' realities. The Howard Journal of Communications, 18, 291311.

PRCA (Public Relations Consultants Association). (2013). Maximizing opportunities: Broadening access to the PR industry. London, UK: Author. Retrieved from http://www.prca.org.uk/assets/files/Broadening\%20access\%20to\%20the\%20PR\%20industry.pdf

Rakow, L., \& Nastasia, D. (2009). On feminist theory of public relations: An example from Dorothy Smith. In Ø. Ihlen, B. van Ruler \& M. Fredriksson (Eds.), Public relations and social theory: Key figures and concepts (pp. 252-277). New York, NY: Routledge.

Resnik, A. (2002). Rethinking learning in the digital age. In G. Kirkman (Ed), The global information technology report: Readiness for the networked world (pp. 32-37). Oxford, UK: Oxford University Press.

Rolin, K. (2009). Standpoint theory as a methodology for the study of power relations. Hypatia, 24(4), 218-226.

Salovey, P., \& Mayer, J. (1989). Emotional intelligence. Imagination, Cognition, and Personality, 9(3), 185-211.

Schmidt, F., \& Hunter, J. (2000). Select on intelligence. In E. Locke (Ed.), The Blackwell handbook of organizational principles (pp. 3-14). Oxford, UK: Blackwell.

Shockley-Zalabak, P. (1994). Understanding organisational communication: Cases, commentaries, and conversations. New York, NY and London, UK: Longman.

Signitzer, B., \& Wamser, C. (2006). Public diplomacy: A specific governmental public relations function. In C. Botan \& V. Hazelton (Eds.), Public relations theory II (pp. 435-464). Mahwah, NJ: Lawrence Erlbaum.

Smith, D. (1974). Women's perspective as a radical critique of sociology. Sociological Inquiry, 44, 113.

Smith, D. (1979). A sociology of women. In J. Sherman \& E. Beck (Eds.), The prism of sex (pp. 135187). Madison, WI: University of Wisconsin Press.

Smith, D. (1987). The everyday world as problematic: A feminist sociology. Boston, MA: Northeastern University Press.

Spicer, C. (2007). Collaborative advocacy and the creation of trust: Toward an understanding of stakeholder claims and risks. In E. Toth (Ed.), The future of excellence in public relations and communication management: Challenges for the next generation (pp. 27-40). Mahwah, NJ: Lawrence Erlbaum.

Sternberg, R. (1985). Beyond IQ: A triarchic theory of intelligence. Cambridge, UK: Cambridge University Press.

Szpir, M. (2002, May-June). Clickworkers on Mars. American Scientist. Retrieved from http://www.americanscientist.org/issues/pub/clickworkers-on-mars 
Toth, E. (2009). Diversity and public relations practice. Gainesville, FL: Institute for Public Relations. Retrieved from http://www.instituteforpr.org/topics/diversity-and-pr-practice

University of Technology Sydney. (2014). Creative intelligence and innovation. Retrieved from http://www.uts.edu.au/future-students/creative-intelligence-and-innovation

van Deursen, A., \& van Dijk, J. (2009). Improving digital skills for the use of online public information services. Government Information Quarterly, 26, 333-340.

van Dijk, J. (2005). The deepening digital divide: Inequality in the information society. Thousand Oaks, CA: Sage.

Wood, J. (1993). Gender and moral voice: Moving from woman's nature to standpoint epistemology. Women's Studies in Communication, 15(1), 1-24.

Wood, J. (1997). Communication theories in action. Belmont, CA: Wadsworth.

Wood, J. (2008). Critical feminist theories. In L. Baxter \& D. Braithwaite (Eds.), Engaging theories in interpersonal communication: Multiple perspectives (pp. 323-334). Thousand Oaks, CA: Sage.

\section{Reference:}

Macnamara J. (2015). Multiple intelligence and minds as attributes to reconfigure PR? A critical analysis. Public Relations Review. doi: 10.1016/j.pubrev.2015.03.002.

http://www.sciencedirect.com/science/article/pii/S036381111500034X

* Jim Macnamara PhD, FPRIA, FAMI, CPM, FAMEC is Professor of Public Communication at the University of Technology Sydney, a position he took up in 2007 after a 30-year professional career spanning journalism, public relations and media research. He is the author of 15 books including Public Relations Theories, Practices, Critiques published by Pearson Australia in 2012, The 21 $1^{\text {st }}$ Century Media (R)evolution: Emergent Communication Practices Peter Lang, New York, 2010, $2^{\text {nd }}$ edition 2014) and Journalism and PR: Unpacking 'Spin', Stereotypes and Media Myths (Peter Lang, New York, 2014). 